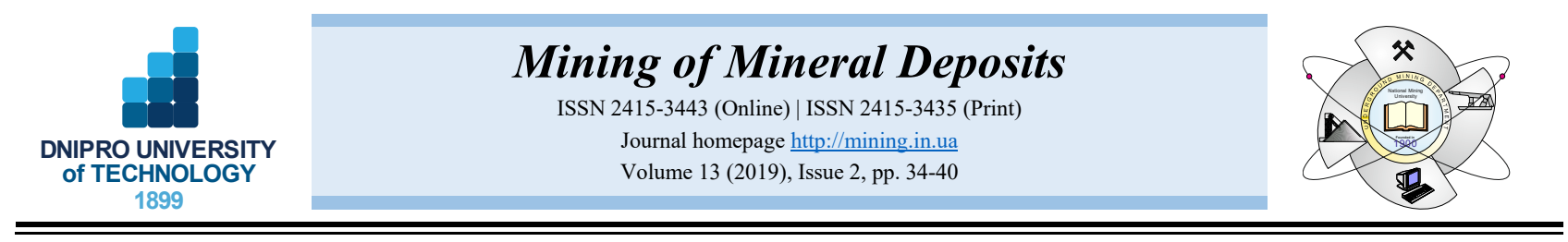

UDC 622.279

https://doi.org/10.33271/mining13.02.034

\title{
USE OF THERMAL AND MAGNETIC DEVICES FOR PREVENTION OF ASPHALTENE, RESIN, AND WAX DEPOSITS ON OIL EQUIPMENT SURFACES
}

\author{
Yu. Vynnykov ${ }^{1}$, A. Manhura ${ }^{1 *}$, O. Zimin ${ }^{1}$, A. Matviienko ${ }^{2}$ \\ ${ }^{I}$ Poltava National Technical Yuri Kondratyuk University, Poltava, Ukraine \\ ${ }^{2}$ SE “UKRNAUKAGEOCENTER”, Poltava, Ukraine \\ *Corresponding author: e-mail mangura2000@gmail.com, tel.+380669345503
}

\begin{abstract}
Purpose. To substantiate the advantages of using a multi-level externally insulated complex of magneto-thermal dewaxing which is located in the oil well and improves production of the formation fluid with high content of asphaltene, resin, and wax deposits (ARWD) by heating and magnetization at certain intervals.

Methods. Experiments proved that the use of a magnetothermal dewaxing device enables (during round-the-clock operation of the well) to double the time between overhauls of the oil wells equipped with sucker-rod pumping units.

Findings. The paper provides an analytical model for calculating the power consumption parameters of the developed multi-level magnetothermal dewaxing complex and the level of the magnetic moment of the formation fluid flow elements in the tubing string pulling unit equipped with this complex. The design of the magnetothermal dewaxing device, as the main constructive link of the multi-level complex of magnetothermal dewaxing, and the material for the manufacture of external insulating casings of such complex elements are described. The design of a multilevel complex of magnetothermal dewaxing and its elements integrated into the tubing string pulling unit and equipped with external insulating casings, is presented. The analytical model for calculating operational parameters of multilevel dewaxing complex equipped with insulating casings is substantiated.
\end{abstract}

Originality. The developed designs of magnetothermal dewaxing devices will allow to use them together with the operation of deep-pumping equipment and in the case of a flowing oil well.

Practical implications. Introduction of a multi-level magnetothermal dewaxing complex on the basis of magnetothermal activators makes it possible to reduce the shortage of such equipment on the markets of oil and gas producing countries.

Keywords: ARWD, magnetic treatment, thermal-magnetic activation, dewaxing device, tubing string, insulating casing

\section{INTRODUCTION}

The formation of asphaltene, resin, and wax deposits (ARWD) in producing wells is prone to emergency situations, mainly because of sucker rod and polished rod breakage, which repeatedly reduces their overhaul period (OP) and production volumes.

Extraction of liquid hydrocarbons is often complicated by the presence of asphaltene or resin and wax deposits in them, which causes formation of deposits inside the tubing string (Chow et al., 2000; GaurinaMeđimurec \& Novak Mavar, 2017). Over time, these deposits - hydrocarbons methane from $\mathrm{C}_{16} \mathrm{H}_{34}$ to $\mathrm{C}_{64} \mathrm{H}_{130}$, silica gel resins, asphalt-resinous compounds, hydrates, and others - worsen, and, in some cases, make it impossible to extract liquid products, since they gradually obturate the passage section of the tubing string.
Insufficient presence of complexes for the prevention of ARWD on oil and gas equipment market, and the tendency to implement combined technological complexes, which are made on the basis of magneto-electrical devices (thermal-magnetic dewaxing units), and also the design of a multi-level complex for deposits prevention should allow placement of thermal-magnetic dewaxing complexes in the zone with a higher level of such deposits.

Crude oil is a complex chemical composition of components which, depending on the structure and the external environment, may be in different states of aggregation. Temperature reduction causes a change in the physical state of the components, leading to the formation of paraffin crystallization centers and their growth (Klassen, 1982).

The intensity of the ARWD formation depends on the predominance of one or more factors that can vary in time and depth, so the number and nature of the deposits

(C) 2019. Yu. Vynnykov, A. Manhura, O. Zimin, A. Matviienko. Published by the Dnipro University of Technology on behalf of Mining of Mineral Deposits. This is an Open Access article distributed under the terms of the Creative Commons Attribution License (http://creativecommons.org/licenses/by/4.0/), which permits unrestricted reuse, distribution, and reproduction in any medium, provided the original work is properly cited. 
are not constant (Suzuki, Kodera, Matsunaga, \& Kurobe, 1993; Mikhlin \& Zhupiev, 1997).

Wax is most intensively deposited on the inner surface of tubing strings. The thickness of deposits gradually increases from the place where they began to form at the depth of $500-900 \mathrm{~m}$ and reaches a maximum at the depth of $50-200 \mathrm{~m}$ from the mouth of the well, then decreases to the thickness of $1-2 \mathrm{~mm}$ in the mouth area (Fig. 1) (Kharchenko, Manhura, Manhura, \& Lartseva, 2017).

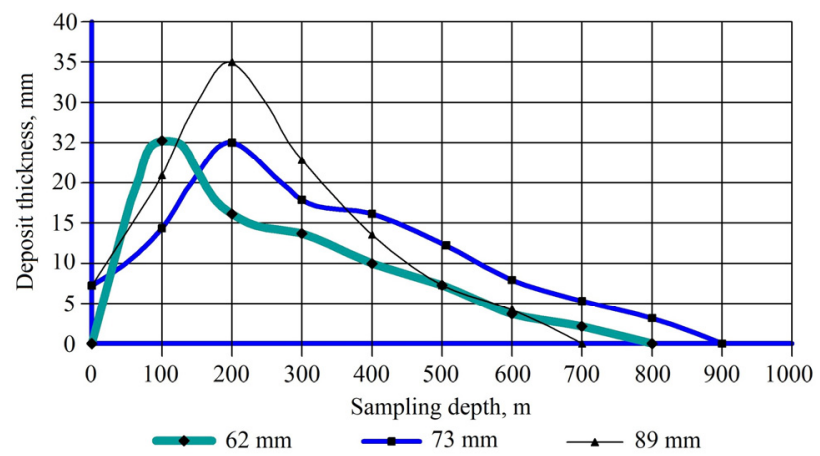

Figure 1. Deposition of ARWD at different well depths

Various means are used to prevent deposits on the walls of the equipment: they include thermal, chemical, physical means and their combination. Special equipment, magnetic devices, chemical solvents, heaters, etc. are also used.

However, all known methods of ARWD control are limited by the conditions of specific fields (Pisareva, Kamenchuk, Andreeva, \& Unger, 2005). For example, the biotechnological method is limited by high reservoir pressures and gas factors, increased content of hydrogen sulfide in oil and temperatures above $40-50^{\circ} \mathrm{C}$, thus it is recommended for wells operated by sucker-rod pumps.

For many deposits in Ukraine, high temperature of petroleum saturation with wax is observed, with temperature reaching $48-50^{\circ} \mathrm{C}$. The melting temperature of wax deposited in wells from oil fields of Ukraine, is also high.

By industrial observations, it was established that ARWD in mining wells of Ukraine decrease with the growth of the wells' flow rate and the low water content in oil (Kharchenko, Manhura, Manhura, \& Lartseva, 2017).

It is known that there are two stages of ARWD formation and growth (Tung et al., 2001). The first stage is the nucleation of crystallization centers and the growth of wax crystals directly on oil contacting surface. The second stage is associated with deposition of larger crystals on wax-covered surface.

Practice shows that the main objects, in which the formation of ARWD is observed, are well pumps, tubing strings, and reservoirs of headers (Zhang, Wang, Li, \& Zhang, 2013).

\section{ANALYSIS OF CURRENT STUDIES}

Mention should be made of works devoted to the analysis and study of wax formation factors and methods of their prevention (Zhang, Wang, Li, \& Zhang, 2013). This research resulted in the development and application of various ways of ARWD removal and designing of special equipment for their use.
We assume that the most promising means of ARWD removal among the existing ones are magnetic devices. They do not change the chemical composition of the formation fluid, are not harmful to the environment, in most cases are installed at an arbitrary interval of tubing string pulling unit and are efficient.

To use magnetic devices, it is necessary to ensure the following conditions: gas factor $\left(20-300 \mathrm{~m}^{3} / \mathrm{m}^{3}\right)$, the presence of the micro-impurities in the form of iron ferromagnetic particles in the wells, the content of asphaltene and resins not less than the content of wax in oil, etc.

In order to optimize the prevention of ARWD and increase the efficiency of borehole complexes use, scientists from Poltava National Technical Yuri Kondratyuk University have created a multi-level system for heating tubing string pulling unit (Fig. 2) made on the basis of tubular heaters. (Kharchenko, Manhura, Manhura, \& Lartseva, 2017).

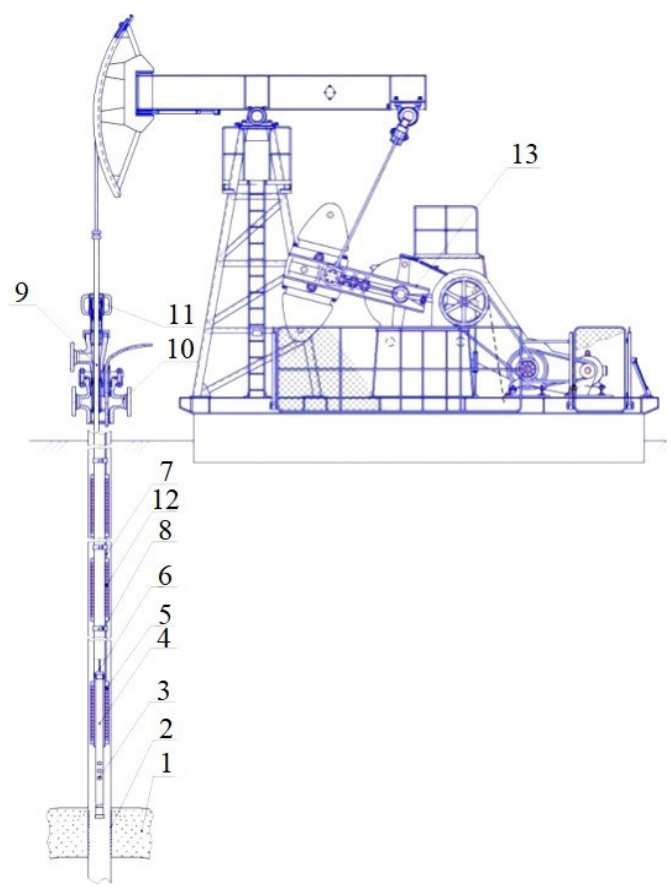

Figure 2. Multi-level system for heating tubing string pulling unit as a part of sucker-rod pumping unit made on the basis of tubular heaters: 1 -layer; 2 - perforation zone; 3-universal gas-sand anchor; 4-the pump; 5, 12-deep tube heaters; 6-sucker rod string; 7-cable; 8-tube strap; 9-stem dipping; 10 -wellhead equipment; 11-assembly unit; 13 - conventional pumping unit

The design and functioning principle of such complex are characterized by the following features:

- it is placed along the length of the ARWD occurrence interval;

- it has an electrical supply, which allows operating in constant and periodic modes;

- it is installed permanently as a part of tubing string pulling unit (tube electric heaters and cable are installed by analogy with the installation of electro-centrifugal pumps);

- it is characterized by a similar principle of operation (direct heating by electric heating devices), which makes it possible to simplify the design and reduce the cost;

- it has a multilevel arrangement of heaters up to 3 $(3-6-9-12)$, in accordance with the number of cable 
cores unified with the cable installation of electrocentrifugal pumps (3 veins), which allows to uniformly heat formation fluid over the interval of deposits;

- it is used both as a part of a flow lift of the oil and gas well, and in combination with pumping methods of oil production;

- it has the highest degree of unification for the existing equipment.

The system for the ARWD removal has a lot of advantages, however, its energy consumption (up to $90 \mathrm{kWh}$ ) and significant heat losses through the walls of tubing and casing are pushing for further scientific and engineering work to improve the multi-level systems of deposits removal.

It is topical to combine operational and constructional advantages of the most promising methods for ARWD removal and introduce them into the multi-level complex which will have a greater degree of unification and simplicity in design.

\section{RESEARCH METHODOLOGY}

The development and research of the operation efficiency of the multilevel ARWD prevention complex made on the basis of magneto-electrical devices (thermal-magnetic dewaxing devices), permanently attached to tubing string pulling unit, will allow the constant or periodic selection of products with their immediate use. It will be possible to use complexes for reduction of ARWD levels on the equipment walls pumped by pipelines, and they will have a greater level of compliance with existing equipment and higher efficiency of labor.

To improve the production of formation fluid with a high ARWD content, the design, composition and principles for determining a multilevel thermal-magnetic dewaxing complex by heating the magnetization on certain intervals are justified. The design of the tube thermal-magnetic dewaxing device is shown in Figure 3.

The body of the tube heater (Fig. 3) comprises a tube, fitted with threaded shanks on both sides for couplings 8 with the tubing string and its parts.

The heating element 5 is a current conductor of high resistance made of nichromic wire placed in sand or magnesium oxide (an electrical insulating conductor), which are placed in a refractory housing enclosed along the longitudinal axis of a tube heater body. The heating element 5 is fixed to the body of the tube 1 with washer 2 . On the body of the tube, there are plug holes 3 , to hold the cable and pull it out. The plug holes contain a drain for the heating element 5 , and are connected with each other by the electric cable 4, the wires located in the heat-insulating hood. For the safety of the heating element 5 from the negative effect of the external factors, the outer cover 6 is placed between the heating element 5 and the insulating casing 7 , which minimizes heat losses from the work of the tube heater.

In the tube thermal-magnetic dewaxing device, a magnetic dewaxer (Fig. 3), which consists of housing 9 equipped with threaded shanks on both sides for connection with tube couplings 8 , is joined to tubing string. On the outer surface of housing 9 , the magnetic block 11 is placed. Between them, permanent magnets 10 are laid. They are clamped with a lid 12 .

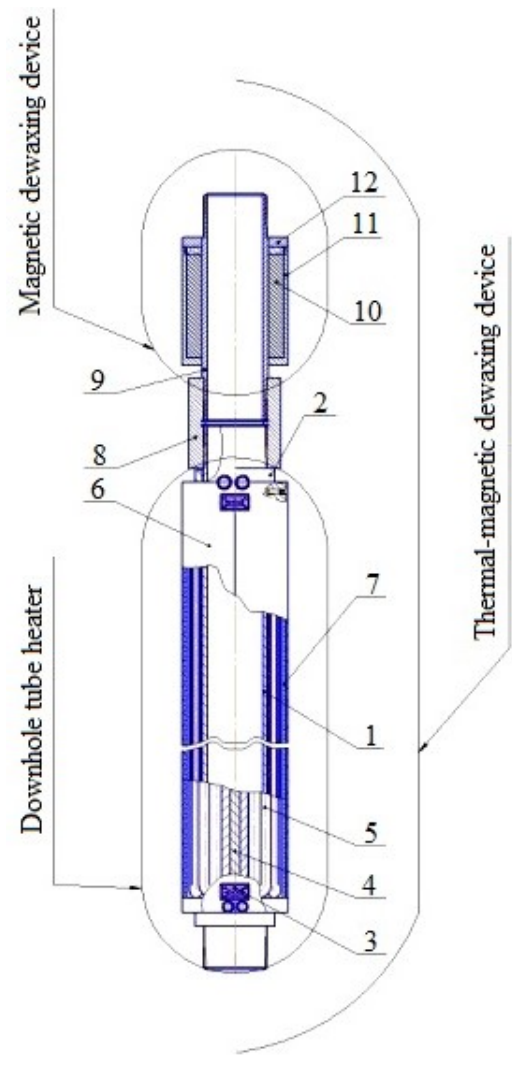

Figure 3. Tube thermal-magnetic dewaxing device: 1 -body; 2-washer; 3-plug hole; 4-cabel; 5-heating element; 6-outer cover; 7-insulating jacket; 8 -tubing coupling; 9-housing of magnetic dewaxing unit; 10 -permanent magnet; 11 -body of magnetic block; 12 - lid

The device is installed as a part of tubing string pulling unit in the interval where ARWD are observed.

On the outer surface of the tubing string, a cable 4 is placed to feed the heating element 5 and connect to the heater through the plug hole 3 .

The fluid containing oil, water and compounds, having a vertical direction of the tubing, enters the inner part of the tube thermal-magnetic dewaxing devices (Das, 2008).

During the movement of the inner part of the tubular heater, there is an increase in the fluid temperature to the parameters at which activation of the motions of molecules and dilution occurs. After that, the product falls into the inner part of the magnetic dewaxing devices, where it is demagnetized. After heating in the tubular heater and the motion of the inner cavity of the magnetic dewaxing device, a phenomenon of ferritization is observed in the fluid - the creation of ferromagnetic centers of internal crystallization, which are determined by a certain magnitude of the magnetic moment and will become the basis (Zhang, Wang, Wang, \& Zhang. 2015).

When the fluid passes through tubing string pulling unit, a decrease in the temperature and the magnetic moment obtained by it in the thermal-magnetic dewaxing devices is observed. In order to restore the parameters to the pulling unit, several intervals are included, magneticthermal dewaxing devices being placed in the beginning. This placement principle allows lifting of the formation fluid in stable ARWD prevention regimes, with the magnitude of the magnetic moment and the level of ferritiza- 
tion of the elements contained in the optimum range to minimize ARWD (Kyrychenko, Samusia, Kyrychenko, \& Goman, 2012; Wang \& Wang, 2014).

With the use of thermal-magnetic dewaxing devices, the level of electricity consumption is significantly reduced, as heaters spread heat throughout the length of the tubing string in the range of $70-85^{\circ} \mathrm{C}$. Individual heating of the formation fluid is also possible in the tube thermal-magnetic dewaxing device to the temperature of $60-70^{\circ} \mathrm{C}$ to activate the ferritization system and create centers for the formation of paraffin crystals, which are applied to the surface by the flow of the fluid. When dewaxing device is placed along the length of the tubing column, they perform ferritization function. Heaters of thermal-magnetic dewaxing devices can be used both in periodic and continuous modes, while magnetic dewaxing devices run constantly.

In order to maintain the required level of temperature and magnetic moment in the inner cavity of the pump and compressor pipes in the multi-level complex of ARWD prevention made on the basis of thermalmagnetic dewaxing units, it is proposed to use external insulating covers which are fixed on the outer surface of the tubing string in the intervals between the levels of thermal-magnetic dewaxing devices placement on the principle of fastening the cable of centrifugal immersed pump installations.

Table 1 shows the coefficients of heat loss through the parts of the developed multi-level ARWD prevention complex made on the basis of thermal-magnetic dewaxing devices equipped with various types of external insulating casings.

Table 1. Indicators of the coefficient of thermal losses through parts of the developed multi-level complex of ARWD prevention, based on thermal-magnetic dewaxing devices, equipped with different types of external insulating casings

\begin{tabular}{clc}
\hline No. & \multicolumn{1}{c}{ Design type } & $\begin{array}{c}\text { Indicator of the heat } \\
\text { loss coefficient, } \varepsilon\end{array}$ \\
\hline 1 & $\begin{array}{l}\text { Two layers of aluminum foil } \\
(0.5 \mathrm{~mm}) \text { with an asbestos } \\
\text { layer }(3.5 \mathrm{~mm}) \text { between them } \\
\text { Two layers of aluminum foil }\end{array}$ & 0.85 \\
2 & $\begin{array}{l}(0.5 \mathrm{~mm}) \text { with a layer of } \\
\text { mineral wool (3.5 mm) } \\
\text { between them }\end{array}$ \\
3 & $\begin{array}{l}\text { Fiberglass, coated on both } \\
\text { sides with aluminum foil - } \\
\text { "Armofol }{ }^{\mathbb{R}} \text { " up to 1 mm } \\
\text { Metallized sheet of } \\
\text { K-SHIELD FIREWRAP", } \\
\text { 4.5 mm }\end{array}$ \\
\hline
\end{tabular}

As the heat-holding ability is high and the thickness of the layer is minimum, it is proposed to use as a material for insulating casing for the developed multi-level complex of ARWD prevention, made on the basis of thermal-magnetic dewaxing devices, a heat-reflective insulating material made on the basis of a glass pane covered with aluminum foil - Armofol $^{\circledR}$. This material can withstand the temperatures up to $+200^{\circ} \mathrm{C}$ and has high chemical and mechanical resistance. Also, this material can detect magnetic and radioactive radiation in the inner cavity of the pipelines. This will maximally hold the magnetic moment of the particles of the formation fluid from the thermal-magnetic dewaxing devices and minimize the amount of thermal-magnetic dewaxing devices in the multi-level ARWD prevention complex (Zhang, Wang, Li, \& Zhang, 2013).

The property that characterizes the operation efficiency of the developed complex is also the $\eta_{v}$ - percentage of the extracted high-viscosity elements from the space of the well to the surface, which is determined using the formula:

$\eta_{v}=\frac{\delta_{\mathrm{ARWD}^{\mathrm{B}}}}{\delta_{\mathrm{ARWD}^{\mathrm{W}}}} \cdot 100 \%$,

where:

$\delta_{\text {ARWD }}{ }^{B}-$ ARWD content at the bottomhole, $\mathrm{g} / \mathrm{dm}^{3}$;

$\delta_{\text {ARWD }^{W}}-$ ARWD content at the wellhead, $\mathrm{g} / \mathrm{dm}^{3}$.

The value $\delta_{\mathrm{ARWD}}{ }^{B}$ is determined by selecting the appropriate samples and performing a chromatographic analysis or using a filtration method. Effective exploitation of the developed multi-level ARWD prevention complex made on the basis of thermal-magnetic dewaxing devices is assumed while providing the value $\eta_{v}$ close to 95 - 98\% (Suzuki, Kodera, Matsunaga, \& Kurobe, 1993).

The characteristics of the multi-level complex of ARWD prevention, based on thermal-magnetic dewaxing device, include the following:

a) for thermal-magnetic dewaxing device: length $9.5 \mathrm{~m}$; tubing string standard size for the manufacture of the casing - $89 \mathrm{~mm}$; external diameter of thermalmagnetic dewaxing device - $130 \mathrm{~mm}$; feed type - alternating and continuous current $220 / 380 \mathrm{~V}$; the temperature of the heating fluid of the reservoir is maximum $90^{\circ} \mathrm{C}$ (nominal $-75^{\circ} \mathrm{C}$ ); power at the maximum mode of formation fluid heating $-15.0-18.5 \mathrm{~kW}$.

b) for a multilevel complex of ARWD prevention, based on thermal-magnetic dewaxing devices: interval of placement - $1000 \mathrm{~m}$; quantity of thermal-magnetic dewaxing devices $-3-6-9-12$ pieces); type of operation under voltage - alternating and continuous.

\section{RESULTS AND DISCUSSION}

Laboratory studies have shown that the rate of wax formation affects allocation process and behavior of gas bubbles in the flow of mixture. It is known that gas bubbles can float suspended wax particles. When bubbles contact the tubes surface, wax particles come in contact with the wall and deposit on it.

In the following, the process of wax deposition increases because of its hydrophobicity. On the wall of the tube, is formed a layer of wax crystals and bubbles in the gas. The smaller gas-saturated layer, the greater density it has. Therefore, denser sediments are formed at the bottom of the lifting pipes where gas bubbles are small and have greater strength adhesion to wax crystals and tube walls (Kharchenko, Manhura, Manhura, \& Lartseva 2017).

The intensity of ARWD formation largely depends on the rate of fluid flow. At low flow rates, the formation of ARWD is quite slow. With speed increase (at transition to turbulent flow regime) deposits intensity initially increases. Further increase of liquid-gas mixture speed (LGM) leads to decrease of ARDW intensity, as the high rate of fluid flow allows wax to keep the crystals in sus- 
pension state and take them out of the well. Furthermore, the flow tears a part of deposits from the walls of the pipes, which explains the decrease of deposits in the range of $0-50 \mathrm{~m}$ from the wellhead. At high speeds, the flow of the mixture cools slower than at lower ones. Likewise, at low speeds, the formation of ARPD slows (Pisareva, Kamenchuk, Andreeva, \& Unger, 2005).

According to the results of industrial enterprises research, the ARWD appear at intervals of 500-900 m (in some cases, from $1200 \mathrm{~m}$ ), which is explained by positive conditions: the temperature of the fluid decreases to $17-20^{\circ} \mathrm{C}$, degassing within this interval, decrease in pressure, etc. The depth of the deposits layer on the inner walls of the tubing can reach $30 \mathrm{~mm}$ and more - until the closure of the passage section of the tubing string. At this interval, there is a need for the use of equipment to prevent this situation or deposition.

The main characteristics of the developed multi-level complex for ARWD prevention, performed on the basis of thermal-magnetic dewaxing devices, are as follows:

- power required by the ground substation to supply the equipment, $\mathrm{W}$;

- power used by the i-th heater as part of the thermalmagnetic dewaxing device in the process of thermal preparation of the formation fluid, W;

- magnitude of the magnetic moment in the lift of a tubing string, $\mathrm{A} \cdot \mathrm{m}^{2}$;

- coefficient of thermal-magnetic dewaxing heaters;

- geometric and weight characteristics of elements, as well as in the whole developed multi-level complex for prevention of ARPD.

Application of a magnetic device allowed increase in the average repair time of wells, complicated by the formation of emulsions and ARWD, on average by 2 times. The introduction of a magnetic device in wells, complicated by the formation of ARWD, has allowed doubling the overhaul period during the chemical treatment of wells (Gavriluk \& Glazkov, 2001).

The use of thermal-magnetic dewaxing units is aimed at increasing the overhaul period of wells due to the action of the directed magnetic field and thermal energy. The mechanism of thermal-magnetic dewaxing device action is directed to the change in the viscosity of the liquid passing through the device (Ivakhnenko, 2006).

The use of thermal-magnetic dewaxing devices can be effective at the operation of wells with deep-well, centrifugal and diaphragm pumps, as well as on oil pipelines.

\section{CONCLUSIONS}

1. The production and industrial use of a multilevel magnetothermal dewaxing complex based on magnetothermal dewaxing devices provides an opportunity to improve the effectiveness of APWD preventing during the extraction of hydrocarbons and their transportation by pipelines.

2 . The projected design of a multi-level magnetothermal dewaxing complex made on the basis of thermal-magnetic activators will consume $45-50 \%$ less power than a similar multi-level heating system of tubing string pulling unit, operating on the principle of wells direct heating.
3. Exploitation of the proposed multi-level complex of magnetothermal dewaxing, based on thermal-magnetic activators, makes it possible to provide a formation fluid with such characteristics, that prevent the ARWD even after the fluid has fallen to the manifold.

4. The projected equipment allows the use of tube thermal-magnetic dewaxing devices, both in the mode of the switched heaters, and in the mode of magnetization without the thermal preparation of the formation fluid. The developed complex is operated in periodic mode if necessary.

\section{ACKNOWLEDGEMENTS}

The present study would have been impossible without support from Poltava National Technical Yuri Kondratyuk University administration. We express our sincere gratitude to Rector Volodymyr Onyshchenko for the opportunity to conduct tests in modern Laboratory of Oil and Gas Technologies.

\section{REFERENCES}

Chow, R., Sawatzky, R., Henry, D., Babchin, A., Wang, Y., Cherney, L., \& Humphreys, R. (2000). Precipitation of wax from crude oil under the influence of a magnetic field. Journal of Canadian Petroleum Technology, 39(06), 1-6. https://doi.org/10.2118/00-06-05

Das, S.K. (2008). Electro magnetic heating in viscous oil reservoir. International Thermal Operations and Heavy Oil Symposium, 1-11. https://doi.org/10.2118/117693-ms

Gaurina-Međimurec, N., \& Novak Mavar, K. (2017). Depleted hydrocarbon reservoirs and $\mathrm{CO}_{2}$ injection wells $-\mathrm{CO}_{2}$ leakage assessment. Rudarsko-Geološko-Naftni Zbornik, $32(2), 15-26$. https://doi.org/10.17794/rgn.2017.2.3

Gavriluk, O.V., \& Glazkov, O.V. (2001). The application of magnetic liquide treatment in oil fields of West Siberia. IOR $2001-11^{\text {th }}$ European Symposium on Improved Oil Recovery. https://doi.org/10.3997/2214-4609.201405977

Ivakhnenko, O.P. (2006). Magnetic analysis of petroleum reservoir fluids, matrix mineral assemblages and fluid-rock interactions. $\mathrm{PhD}$ Thesis. Edinburgh, United Kingdom: Institute of Petroleum Engineering.

Kharchenko, M., Manhura, A., Manhura, S., \& Lartseva, I. (2017). Analysis of magnetic treatment of production fluid with high content of asphalt-resin-paraffin deposits. Mining of Mineral Deposits, 11(2), 28-33.

https://doi.org/10.15407/mining11.02.028

Klassen, V. (1982). Omagnichevanie vodnykh sistem. Moskva, Rossiya: Khimiya.

Kyrychenko, Y., Samusia, V., Kyrychenko, V., \& Goman, O. (2012). Experimental investigation of aeroelastic and hydroelastic instability parameters of a marine pipeline. Geomechanical Processes During Underground Mining, 163-167. https://doi.org/10.1201/b13157-28

Mikhlin, Y.V., \& Zhupiev, A.L. (1997). An application of the inch algebraization to the stability of non-linear normal vibration modes. International Journal of Non-Linear Mechanics, 32(2), 393-409.

https://doi.org/10.1016/s0020-7462(96)00047-9

Pisareva, S.I., Kamenchuk, Y.A., Andreeva, L.N., \& Unger, F.G. (2005). The nature of formation and dissolution of asphaltresin-wax deposits. Chemistry and Technology of Fuels and Oils, 41(6), 480-485. https://doi.org/10.1007/s10553-006-0013-3 
Suzuki, H., Kodera, S., Matsunaga, H., \& Kurobe, T. (1993) Study on magnetic field-assisted polishing ( $2^{\text {nd }}$ Report $)-$ effect of magnetic field distribution on removal distribution. Journal of the Japan Society for Precision Engineering, 59(11), 1833-1838. https://doi.org/10.1016/0141-6359(94)90185-6

Tung, N., Vuong, N., Bui Quang, K., Vinh, N., Hung, P., Hue, V., \& Hoe, L. (2001). Studying the mechanism of magnetic field influence on paraffin crude oil viscosity and wax deposition reductions. Proceedings of SPE Asia Pacific Oil and Gas Conference and Exhibition, 1-7. https://doi.org/10.2523/68749-ms

Wang, L.J., \& Wang, W. (2014). Paraffin depositing mechanism and prediction methods of paraffin removal cy- cle. Applied Mechanics and Materials, (675-677), 1512-1516.

https://doi.org/10.4028/www.scientific.net/amm.675-677.1512

Zhang, W.W., Wang, D.D., Wang, T.T., \& Zhang, S.C. (2015). Study on the mechanism of magnetic paraffin control of crude oil based on the reorientation of paraffin crystals induced by magnetic field. Applied Mechanics and Materials, (743), 137-141.

https://doi.org/10.4028/www.scientific.net/amm.743.137

Zhang, W.W., Wang, T.T., Li, X., \& Zhang, S.C. (2013). The effect of magnetic field on the deposition of paraffin wax on the oil pipe. Advanced Materials Research, (788), 719-722. https://doi.org/10.4028/www.scientific.net/amr.788.719

\section{ВИКОРИСТАННЯ ТЕПЛОМАГНІТНИХ ПРИСТРОЇВ ДЛЯ ЗАПОБІГАННЯ АСПВ НА ПОВЕРХНЯХ НАФТОПРОМИСЛОВОГО ОБЛАДНАННЯ}

\section{Ю. Винников, А. Мангура, О. Зімін, А. Матвієнко}

Мета. Обгрунтування переваг використання багаторівневого комплексу магнітотеплової депарафінізації, який розміщується в нафтовидобувній свердловині та поліпшує видобуток пластового флюїду з великим вмістом асфальтосмолопарафінистих відкладень (АСПВ), шляхом підігрівання й намагнічування у визначених інтервалах і оснащеного зовнішніми ізолюючими кожухами.

Методика. Аналіз досліджень впливу багаторівневого комплексу магнітотеплової депарафінізації на пластовий флюїд з високим вмістом асфальтенів, смол і парафінів. Досліджено зміни фізико-хімічних властивостей нафти при застосуванні магнітотеплових депарафінізаторів, які направлені на збільшення міжочисного (міжремонтного) періоду свердловин за рахунок дії направленого магнітного поля та теплової енергії. Методичною основою здійснених досліджень $є$ аналіз і розгляд використаної літератури, а також позитивний виробничий досвід усунення АСПВ під час видобутку вуглеводнів з підвищеним вмістом АСПВ із використанням інженерного аналізу й оцінки отриманих результатів.

Результати. Встановлено, що використання багаторівневого комплексу магнітотеплової депарафінізації дає можливість підвищити ефективність запобігання АСПВ під час видобутку високов'язкої нафти та ії транспортуванні трубопроводами. Встановлено, що для зменшення інтенсивності АСПВ трубні магнітотеплові депарафінізатори можливо використовувати як у режимі увімкнених підігрівачів, так і в режимі намагнічування без теплової підготовки пластового флюїду. Виявлено, що застосування магнітного пристрою дозволило збільшити середній міжремонтний період свердловин, ускладнених утворенням емульсій і $\mathrm{ACПВ,} \mathrm{у} \mathrm{середньому} \mathrm{в} 2$ рази.

Наукова новизна. Виявлено, що в процесі встановлення у свердловину багаторівневого комплексу магнітотеплової депарафінізації, виконаного на основі магнітотеплових активаторів, змінює фізико-хімічні властивості нафти, які дозволяють запобігати АСПВ навіть після потрапляння флюїду до маніфольду.

Практична значимість. Результати впровадження багаторівневого комплексу магнітотеплової депарафінізації, виконаного на основі магнітотеплових активаторів, дають можливість зменшити дефіцит подібного устаткування на ринках нафтогазовидобувних країн.

Ключові слова: АСПВ, магнітна обробка, магнітотеплова активачія, депарафінізатор, насосно-компресорні труби, ізолюючий кожух

\section{ИСПОЛЬЗОВАНИЕ ТЕПЛОМАГНИТНИХ УСТРОЙСТВ ДЛЯ ПРЕДУПРЕЖДЕНИЯ АСПО НА ПОВЕРХНОСТЯХ НЕФТЕПРОМЫШЛЕННОГО ОБОРУДОВАНИЯ}

\section{Ю. Винников, А. Мангура, О. Зимин, А. Матвиенко}

Цель. Обоснование преимуществ использования многоуровневого комплекса магнитотепловой депарафинизации, который размещается в нефтедобывающей скважине и улучшает добычу пластового флюида с большим содержанием асфальтосмолопарафинистих отложений (АСПО), путем подогрева и намагничивания в определенных интервалах и оснащенного внешними изолирующими кожухами.

Методика. Анализ исследований влияния многоуровневого комплекса магнитотепловой депарафинизации на пластовый флюид с высоким содержанием асфальтенов, смол и парафинов. Исследованы изменения физико-химических свойств нефти при применении магнитотепловых депарафинизаторов, которые направлены на увеличение межочистного (межремонтного) периода скважин за счет действия направленного магнитного поля и тепловой энергии. Методической основой осуществленных исследований является анализ и рассмотрение использованной литературы, а также положительный производственный опыт устранения АСПО при добыче углеводородов с повышенным содержанием АСПО с использованием инженерного анализа и оценки полученных результатов.

Результаты. Установлено, что использование многоуровневого комплекса магнитотепловой депарафинизации позволяет повысить эффективность предотвращения АСПО при добыче высоковязкой нефти и ее транспортировке по трубопроводам. Установлено, что для уменьшения интенсивности АСПО трубные магнито- 
тепловые депарафинизаторы можно использовать как в режиме включенных подогревателей, так и в режиме намагничивания без тепловой подготовки пластового флюида. Выявлено, что применение магнитного устройства позволило увеличить средний межремонтный период скважин, осложненных образованием эмульсий и АСПО, в среднем в 2 раза.

Научная новизна. Выявлено, что в процессе установки в скважину многоуровневого комплекса магнитотепловой депарафинизации, выполненного на основе магнитотепловых активаторов, меняет физико-химические свойства нефти, которые позволяют предотвращать АСПО даже после попадания флюида в манифольд.

Практическая значимость. Результаты внедрения многоуровневого комплекса магнитотепловой депарафинизации, выполненного на основе магнитотепловых активаторов, дают возможность уменьшить дефицит подобного оборудования на рынках нефтегазодобывающих стран.

Ключевые слова: АСПО, магнитная обработка, магнитотепловая активация, депарафинизатор, насоснокомпрессорные трубы, изолирующчий кожух

\section{ARTICLE INFO}

Received: 25 September 2018

Accepted: 3 April 2019

Available online: 6 May 2019

\section{ABOUT AUTHORS}

Yurii Vynnykov, Doctor of Technical Sciences, Professor of the Oil and Gas Engineering and Technologies Department, Poltava National Technical Yuri Kondratyuk University, 24 Pershotravnevyi Ave., 36011, Poltava, Ukraine. E-mail: vynnykov@ukr.net

Andrii Manhura, Senior Instructor of the Oil and Gas Engineering and Technologies Department, Poltava National Technical Yuri Kondratyuk University, 24 Pershotravnevyi Ave., 36011, Poltava, Ukraine. E-mail: mangura2000@gmail.com

Oleh Zimin, Instructor of the Oil and Gas Engineering and Technologies Department, Poltava National Technical Yuri Kondratyuk University, 24 Pershotravnevyi Ave., 36011, Poltava, Ukraine. E-mail: ziminoleg2@gmail.com

Andrii Matviienko, Candidate of Technical Sciences, Assistant Director of the Well Surveying and Mineral Deposits Exploration Department, SE "UKRNAUKAGEOCENTER", 53 Marshala Biriuzova St, 36007, Poltava, Ukraine. E-mail: novator11977@ukr.net 